\title{
EXPRESSIVE WRITING MENINGKATKAN SELF-ESTEEM PECANDU NARKOBA DI PROGRAM REHABILITASI BNN BADDOKA
}

\author{
Nurul Utami Safaruddin 1 \\ Sitti Murdiana \\ Ahmad Ridfah \\ Fakultas Psikologi, Universitas Negeri Makassar
}

\begin{abstract}
Expressive writing is one of the interventions that is able to influence self-esteem improvement on drug addicts. This research aimed to figure out the effectivity of expressive writing in improving self-esteem of drug addicts. It applied quasy experimental design, one-group pretestpostest design. The research subject were 8 drug addicts. Self-esteem scale was used as the research measurement adopted from Widyastuti (2002). The result reveals that expressive writing improved self-esteem of drug addicts, the increase was seen from the significant difference between self-esteem score at pretest and posttest ( $W=2$, mean pretest $=11,625$, mean posttest $=14,625, p=0.026)$. Expressive writing can be used to improve self-esteem of drug addicts, so it can also be given in rehabilitation program.
\end{abstract}

Keywords: addicts, expressive writing, rehabilitation, self-esteem.

\begin{abstract}
ABSTRAK: Expressive writing merupakan salah satu bentuk intervensi yang dapat mempengaruhi peningkatan self-esteem pada pecandu narkoba. Penelitian ini bertujuan untuk mengetahui efektivitas expressive writing dalam meningkatkan self-esteem pecandu narkoba. Penelitian ini menggunakan desain penelitian kuasi eksperimen one-group pretest-posttest design. Subjek dalam penelitian ini berjumlah 8 orang. Alat ukur yang digunakan dalam penelitian ini menggunakan skala self-esteem yang diadaptasi dari Widyastuti (2002). Hasil dari penelitian ini menunjukkan bahwa expressive writing efektif dalam meningkatkan self-esteem pecandu narkoba, peningkatan tersebut terlihat dari adanya perbedaan yang signifikan antara skor self-esteem saat pretest dengan posttest $(\mathrm{W}=2$, mean pretest $=11,625$, mean posttest $=14,625, \mathrm{p}=0,026)$. Expressive writing dapat digunakan untuk meningkatkan self-esteem pecandu narkoba, sehingga dapat pula diberikan dalam program rehabilitasi.
\end{abstract}

Kata kunci: expressive writing, pecandu, rehabilitasi, self-esteem.

\footnotetext{
${ }^{1}$ Korespondensi mengenai isi artikel ini dapat melalui: tamiinurul@gmail.com
} 
Zat-zat adiktif yang sangat berbahaya bagi tubuh dan menjadi masalah bagi umat manusia di berbagai belahan bumi, sangat banyak ditemukan saat ini. Salah satunya dikenal dengan narkotika, psikotropika, dan zat adiktif lainnya atau yang dikenal dengan istilah narkoba. Narkotika adalah zat atau obat yang berasal dari tanaman atau bukan tanaman, baik sintetis maupun semi sintetis, yang dapat menyebabkan penurunan atau perubahan kesadaran, hilangnya rasa, mengurangi sampai menghilangkan rasa nyeri, dan dapat menimbulkan ketergantungan (UU No. 35/2009 tentang Narkotika). Sementara, yang dimaksud zat adiktif ialah obat-obatan golongan psikotropika atau obat yang bekerja menurunkan fungsi otak serta merangsang susuan syaraf pusat sehingga menimbulkan reaksi berupa halusinasi, ilusi, gangguan cara berpikir, perubahan perasaan yang tiba-tiba, dan menimbulkan rasa kecanduan pada pemakainya (bnn.go.id, 2019).

Pada tahun 1990-an ekstasi, shabu, dan heroin (termasuk zat adiktif atau psikotropika) memasuki pasar Indonesia. Penyebaran ini terus berkembang, masalah penyalahgunaan obat atau penggunaan narkoba di Indonesia kemudian meluas dan makin mengkhawatirkan, tidak saja di perkotaan, melainkan sudah menjangkau ke pedesaan (Kementerian Kesehatan RI, 2014).

Penyalahgunaan obat ini dapat berimplikasi pada perilaku kecanduan. Volkow (2014) mengemukakan bahwa kecanduan adalah penyakit otak kronis yang ditandai dengan pencarian dan penggunaan obat secara kompulsif terlepas dari konsekuensi yang berbahaya.

Penggunaan narkoba merupakan masalah yang sangat kompleks, dan memerlukan upaya penanggulangan secara komprehensif dengan melibatkan kerja sama multidisipliner, multisektor, dan peran serta masyarakat secara aktif yang harus dilaksanakan secara berkesinambungan, konsekuen, dan konsisten. Indonesia saat ini tidak hanya sebagai transit perdagangan gelap serta tujuan peredaran narkoba, melainkan juga menjadi produsen dan pengekspor (Kementerian Kesehatan RI, 2014). Deputi Bidang Pencegahan Kementerian Kesehatan RI. (2017) mengemukakan bahwa individu yang menggunakan narkoba akan mengalami dampak pada terhambatnya kerja otak, memperlambat aktivitas tubuh, menyebabkan distorsi persepsi, pikiran, dan lingkungan, serta meningkatkan risiko gangguan mental. Bahkan secara eksplisit World Health Organization (WHO) (2016) menjelaskan individu atau pecandu akan mengalami gejala mental seperti kegelisahan, depresi, agresivitas, kehilangan nafsu makan, dan gangguan tidur.

Selain berdampak pada permasalahan fisik dan psikologis, penggunaan narkoba juga berdampak pada perkembangan kepribadian individu yaitu self-esteem. Dalam penelitiannya, Akhter (2013) melaporkan bahwa penggunaan obatobatan terlarang sangat memengaruhi perkembangan kepribadian individu yang berhubungan dengan self-esteem.

Adapun penyebab individu menggunakan narkoba menurut Steffenhagen (1980) ialah karena adanya ketersediaan, penerimaan sosial, dan tekanan sosial yang menandakan rendahnya self-esteem

Self-esteem merupakan bagian dari perkembangan kepribadian. Self esteem ialah keseluruhan cara yang digunakan untuk menilai diri atau penilaian pribadi mengenai kelayakan yang diungkapkan dalam sikap individu terhadap diri sendiri. Individu dengan self-esteem yang tinggi cenderung melaporkan tingkat kecerdasan dan kebahagiaan yang tinggi (Santrock, 2012). Self-esteem berkaitan dengan hal-hal negatif seperti depresi, merokok, agresi, dan bereksperimen dengan obat-obatan terlarang atau alkohol (Hefferon \& Boniwell, 2011). 
Karakteristik penyebab individu menggunakan obat-obat terlarang adalah self-esteem yang rendah. Individu dengan self-esteem rendah akan kehilangan kepercayaan diri dan tidak mampu menilai kemampuan diri. Hal tersebut mengakibatkan individu tidak mampu mengekspresikan dirinya di lingkungan sosial dan juga cenderung membatasi diri dalam bersikap terbuka pada orang lain, mendengarkan kritik, meminta bantuan, dan pemecahan masalah (Gunawan, Priyatama, \& Setyanto, 2016). Self-esteem rendah menjadi alasan individu menggunakan narkoba yang dibuktikan dengan adanya keinginan to feel good, to feel better, to do better, dan curiosity (Volkow, 2014).

Menurut Coopersmith (1967) aspekaspek self-esteem ialah adanya kekuasaan, keberartian, kemampuan, dan kebaikan, sedangkan faktor yang memengaruhi selfesteem individu adalah apa yang dirasakan oleh individu itu sendiri. Perasaan yang berasal dari dalam diri individu dan terkait dengan lingkungannya. Self-esteem individu dapat dilihat dari bagaimana ia menilai dirinya sendiri akibat pengaruh dari lingkungan sekitar.

Self-esteem rendah pada pecandu narkoba dapat ditingkatkan dengan metode pengungkapan diri. Lehrhroff (2014) menjelaskan bahwa expressive writing merupakan metode yang efektif untuk pengungkapan, karena dapat memperbaiki kondisi psikologis baik jangka panjang dan jangka pendek, kesehatan fisik di berbagai gejala, kondisi dan populasi, serta efektif saat difokuskan ke stressor. Bahkan, metode ini bermanfaat bagi kesehatan individu ketika menulis dengan intens mengenai pengalaman positif dan negatif individu. Hal itu ditegaskan oleh Cohen (2010) bahwa expressive writing dapat menurunkan aktifitas sistem saraf simpatik dan mengurangi tingkat pengalaman menyedihkan dan menyakitkan.
Expressive writing menurut beberapa ahli dinyatakan sebagai: salah satu teknik terapi expressive yang digunakan untuk konseling, psikoterapi, rehabilitasi, dan kesehatan (Malchiodi, 2005); merupakan salah satu cara eksplorasi dan pemikiran melalui tulisan (Baikie \& Wilhelm, 2005).

Pemikiran yang dimaksud Baikie dan Wilhelm (2005) di atas adalah pemikiran yang mendalam mengenai pengalaman yang traumatis dan emosional. Individu yang melakukan terapi expressive writing memungkinkan baginya menghadapi trauma atau pengalaman emosional, mengakui emosi yang terkait, dan menurunkan tekanan tubuh. Expressive writing melibatkan penerjemahan peristiwa ke dalam kata-kata mereka sendiri yang kemudian memungkinkan individu untuk memahami pemikiran aslinya mengenai traumatis dan emosional.

Expressive writing merupakan metode menuliskan ekspresi emosi ke dalam buku, blog atau jurnal pribadi dalam bentuk narasi (Rahmawati, 2014), yang berisi kata-kata dan kategori kata. Pennebaker (1997) mengemukakan bahwa kategori kata yang termasuk dalam expressive writing adalah kata-kata emosi negatif (sedih dan marah), kata-kata emosi positif (senang dan ketawa), kata-kata sebab akibat (karena dan alasan), dan kata-kata pemahaman (mengerti dan menyadari). Kategori kata tersebut dapat memprediksi kesehatan fisik individu. Pernyataan Pennebaker (1997) dibuktikan oleh penelitian yang dilakukan Indah, Afiatin, dan Astuti (2011) bahwa menulis dapat memfasilitasi penyesuaian terhadap peristiwa yang penuh dengan tekanan dengan mengintegrasikan keyakinan, emosi, dan pengalaman, sehingga individu dapat lebih baik memahami peristiwa dan mengidentifikasi cara-cara guna mengatasinya.

Indah, Afiatin, dan Astuti (2011) mengemukakan bahwa model terapi yang berorentasi pada katarsis, seperti menulis 
pengalaman emosional, memiliki daya ubah yang sedemikian dramatis sehingga secara otomatis dapat mengubah kepribadian atau mengubah proses regulasi diri seseorang yang menyertai perubahan kepribadiannya. Terapi menulis pengalaman emosional bermanfaat serta memungkinkan individu melepaskan emosi negatif yang selama ini dipendam, selain juga memberikan peluang pada individu untuk mengekspresikan keluar emosi negatif, seperti rasa marah, sedih, dan malu, tanpa khawatir mendapatkan respon negatif dari lingkungan sekitar. Dengan mengungkapkan dan mengekspresikan emosi-emosi negatif yang terpendam, maka terjadi pelepasan ketegangan. Berdasarkan pemaparan di atas, penulis tertarik untuk mengetahui efektivitas expressive writing dalam meningkatkan self-esteem pecandu narkoba di program rehabilitasi BNN Baddoka. Hipotesis dalam penelitian ini adalah expressive writing efektif dalam meningkatkan self-esteem pecandu narkoba di program rehabilitasi BNN Baddoka.

\section{METODE PENELITIAN}

\section{Subjek Penelitian}

Partisipan dalam penelitian ini melibatkan 8 partisipan dengan kriteria, yaitu pecandu narkoba di program rehabilitasi BNN Baddoka, laki-laki 13-40 tahun, mampu melahirkan pikiran atau perasaan dengan tulisan ekspresif, senang menyampaikan pendapat dengan cara menulis. Dalam hal ini, yang dimaksud pecandu, mengacu pada definisi dari Departemen Pendidikan Nasional (2011) ialah pengisap candu, pemadat, dan penggemar.

\section{Desain Penelitian}

Desain eksperimen yang digunakan dalam penelitian ini adalah one-group pretest-posttest design. Teknik analisis datanya menggunakan Paired-Sample t-test dengan uji Wilcoxon.

\section{Prosedur Intervensi}

Prosedur intervensi expressive writing diawali dengan pemberian penjelasan mengenai expressive writing dan waktu pemberian intervensinya. Setelah itu dilanjutkan dengan pembagian kertas hvs kosong dan pulpen kepada partisipan. Setelah semua partisipan mendapatkan kertas dan pulpen, peneliti membacakan instruksi expressive writing dan memberi tahu durasi intervensi yaitu selama 30 menit. Intervensi expressive writing diberikan selama empat hari berturut-turut dengan durasi 30 menit setiap harinya. Pada hari pertama sebelum diberikan intervensi, seluruh partisipan diukur self-esteemnya baru kemudian diberikan intervensi. Di hari kedua dan ketiga, partisipan hanya menulis saja dengan durasi 30 menit tanpa kegiatan lainnya. Hari keempat partisipan diberi intervensi expressive writing kembali, kemudian partisipan kembali diukur selfesteemnya. Setelah itu seluruh partisipan diminta mengikuti sesi wawancara yang dilakukan oleh peneliti.

\section{Teknik Analisis Data}

Skala yang digunakan dalam penelitian ini adalah skala self-esteem yang diadaptasi dari Widyastuti (2002). Hasil daya diskriminasi aitem skala self-esteem menunjukkan bahwa terdapat 14 aitem yang bertahan dengan nilai koefisien korelasi aitem total antara 0,234 sampai 0,783 . Hasil validitas faktorial menunjukkan bahwa dari 14 aitem hasil daya diskriminasi aitem, tersisa enam aitem yang memiliki nilai faktor loading sama atau di atas 0,5. Dengan demikian, jumlah total aitem pada skala selfesteem yang digunakan dalam penelitian ini berjumlah enam aitem. Reliabilitas skala self-esteem menunjukkan bahwa skala self- 
esteem tergolong sangat bagus dengan nilai Alpha Cronbach 0,992.

\section{HASIL PENELITIAN}

Partisipan penelitian ini ialah residen entry unit Balai Rehabilitasi BNN Baddoka yang berjenis kelamin laki-laki dengan rentang usia 13 tahun hingga 40 tahun. Para partisipan memiliki riwayat penggunaan narkotika mulai rentang satu tahun penggunaan hingga dua belas tahun. Partisipan residen di Balai Rehabilitasi BNN Baddoka adalah mereka yang ditangkap polisi dan juga penyerahan dari pihak keluarga.

Berdasarkan data yang diperoleh, hasil analisis deskiptif menunjukkan bahwa partisipan penelitian memiliki self-esteem rendah hingga sedang. Dari kedelapan partisipan diketahui bahwa tujuh dari mereka memiliki skor self-esteem yang sedang dan satu partisipan mendapat skor yang rendah. Seluruh partisipan penelitian mengaku memiliki perasaan lemah terhadap dirinya sendiri dan kurang percaya dengan kemampuan yang mereka miliki sehingga mencari hal baru yang dapat menambah semangat dengan menggunakan narkotika. Hal tersebut sejalan dengan teori bahwa selfesteem berkaitan dengan hal-hal negatif seperti depresi, merokok, agresi, dan bereksperimen dengan obat-obatan terlarang atau alkohol (Hefferon \& Boniwell, 2011).

Hasil uji hipotesis penelitian mengenai pengaruh expressive writing dalam meningkatkan self-esteem pecandu narkoba di program rehabilitasi BNN Baddoka dengan menggunakan uji Wilcoxon menunjukkan hasil nilai signifikansi sebesar $\mathrm{p}=0,026(\mathrm{p}<0,05)$.

Hasil wawancara yang dilakukan diketahui bahwa $50 \%$ partisipan dapat memahami dan mengenali dirinya sendiri, $37,5 \%$ partisipan mengakui merasakan penyesalan, dan $87,5 \%$ partisipan mengaku lega setelah menulis selama empat hari.

Tabel 1. Subjek Penelitian

\begin{tabular}{llllllll}
\hline No. & Inisial & Usia & $\begin{array}{l}\text { Pret } \\
\text { est }\end{array}$ & Kategori & $\begin{array}{l}\text { Postt } \\
\text { est }\end{array}$ & Kategori & $\begin{array}{l}\text { Lama } \\
\text { Penggunaan }\end{array}$ \\
\hline 1 & MI & 18 Tahun & 7 & Rendah & 17 & Tinggi & 2 Tahun \\
2 & DZ & 17 Tahun & 11 & Sedang & 14 & Sedang & 4 Tahun \\
3 & IR & 22 Tahun & 15 & Sedang & 15 & Sedang & 2 Tahun \\
4 & MAM & 21 Tahun & 15 & Sedang & 16 & Tinggi & 6 Tahun \\
5 & MRA & 26 Tahun & 14 & Sedang & 18 & Tinggi & 1 Tahun \\
6 & MZH & 16 Tahun & 8 & Sedang & 11 & Sedang & 3 Tahun \\
7 & RF & 28 Tahun & 8 & Sedang & 13 & Sedang & 12 Tahun \\
8 & P & 18 Tahun & 15 & Sedang & 13 & Sedang & 3 Tahun \\
\hline
\end{tabular}

\section{Pembahasan}

Pengukuran yang diberikan kepada seluruh partisipan menunjukkan hasil bahwa enam dari delapan partisipan mengalami peningkatan skor, satu partisipan mengalami penurunan skor, dan satu partisipan tidak mengalami perubahan skor baik sebelum dan setelah pemberian expressive writing. Pengukuran dilakukan dengan menggunakan skala self-esteem dengan metode pra test dan pascates. Pengukuran dilakukan sebelum dan setelah 
diberikan perlakuan expressive writing kepada partisipan selama empat hari.

$$
\text { Hasil analisis deskriptif }
$$

menunjukkan bahwa sebagian residen di Balai Rehabilitasi BNN memiliki self-esteem rendah hingga sedang. Hal tersebut sejalan dengan penelitian Akhter (2013) bahwa penggunaan obat-obatan terlarang berpengaruh pada perkembangan kepribadian individu, khususnya terkait dengan self-esteem. Ketika pengguna mengonsumsi obat-obatan terlarang dengan level yang tinggi, ia akan mengalami hambatan pikiran. Akibatnya, individu yang mengonsumsi obat-obat terlarang menjadi tidak berguna dan tidak berharga. Lingkungan dan keluarga menganggapnya sebagai individu yang buruk, dan akan mengabaikan mereka. Hal inilah yang menjadikan individu yang mengonsumsi obat-obat terlarang memiliki self-esteem rendah.

Pengukuran self-esteem dalam penelitian ini menggunakan skala selfesteem mengacu pada aspek Coopersmith (1967) yaitu, kekuasaan, keberartian, kemampuan, dan kebaikan. Dari keempat aspek tersebut, aspek kemampuan mengalami peningkatan skor dari sebelum dan setelah diberikan perlakuan. Dari kedelapan partisipan, lima partisipan mengalami peningkatan skor pada aspek kemampuan. Hal ini menandakan bahwa pengukuran aspek kemampuan pada pecandu narkoba dapat meningkat dengan diberikannya perlakuan terapi menulis. Adapun di aspek kekuasaan diperoleh hasil bahwa terdapat empat partisipan yang tidak mengalami perubahan skor, serta dua partisipan mengalami peningkatan sekaligus penurunan skor.

$$
\text { Pada aspek keberartian, }
$$

menunjukkan bahwa terdapat empat partisipan yang mengalami peningkatan skor sebelum dan setelah diberikan perlakuan serta empat partisipan mengalami penurunan skor pengukuran.
Aspek kebaikan menunjukkan bahwa empat partisipan mengalami peningkatan skor pengukuran, tiga partisipan tidak mengalami perubahan skor, dan satu partisipan mengalami penurunan skor pengukuran sebelum dan setelah diberikan perlakuan.

Hasil wawancara yang dilakukan terhadap delapan partisipan menunjukkan bahwa besarnya pengaruh teman sebaya dan lingkungan atas penggunaan narkotika pada mereka. Para partisipan mengaku bahwa adanya ajakan teman dan rasa penasaran terhadap narkotika dan juga dilatarbelakangi dengan masalah yang dialami pada saat itu, memudahkan mereka mengonsumsinya. Hal tersebut sejalan dengan teori yang dikemukakan oleh Steffenhagen (1980) bahwa gaya hidup yang membentuk kepribadian dan orientasi tujuan menjadi penyebab individu menggunakan obat-obat terlarang. Pola penyalahgunaan obat terlarang digunakan sebagai mekanisme mengatasi berbagai situasi menekan, seperti pengaruh lingkungan sosial dimana individu sangat mudah terpengaruh terhadap tekanantekanan sebaya dan adanya kebutuhan untuk diterima. Hal tersebut menyebabkan individu menetapkan tujuan yang tinggi dan menjaga pengembangan kompensasi dan ketidakmampuan mencapai tujuan mengakibatkan individu menggunakan narkoba sebagai mekanisme untuk menyelesaikan.

Hasil wawancara yang dilakukan, kedelapan partisipan penelitian mengaku senang saat mengonsumsi narkotika, merasa menambah stamina, dan terbebas dari masalah. Hal itu sejalan dengan pendapat Volkow (2014) bahwa individu menggunakan narkoba karena adanya keinginan to feel good, to feel better, to do better, dan curiosity. To feel good ketika individu menggunakan narkoba akan menghasilkan perasaan senang, karena kandungan pada narkoba menyebabkan 
candu yang memengaruhi perasaan kekuasaan individu, percaya diri, dan meningkatkan energi. To feel better adalah kondisi yang dicari individu yang menderita kecemasan sosial, stres, dan depresi yang kemudian mulai menggunakan narkoba untuk mengurangi perasaan tertekan dan untuk memiliki perasaan lebih baik, karena stres berperan penting dalam menggunakan narkoba, melanjutkan, atau kambuh. To do better adalah usaha individu yang merasa tertekan untuk meningkatkan atau memperbaiki kemampuan kognitif, kemampuan atletik, yang berperan penting dalam percobaan dan pengkonsumsian narkoba serta menggunakan narkoba sebagai stimulus untuk berperilaku lebih baik. Curiosity adalah keadaan dimana individu menjadi objek yang sangat mudah diserang atau terpengaruh oleh tekanan kelompok sebaya. Remaja lebih mungkin terikat dalam resiko atau perilaku berani untuk memengaruhi teman dan mengekspresikan kebebasannya dari orang tua dan aturan sosial.

Selama pemberian perlakuan expressive writing, partisipan terus menulis sampai batas waktu habis, yaitu 30 menit. Selama proses menulis dan paska menulis, kedelapan partisipan mengaku merasa lega karena dapat mengeluarkan isi pikiran mereka. Partisipan juga merasa senang setelah menulis selama empat hari.

Hasil wawancara yang dilakukan diketahui bahwa $50 \%$ partisipan mampu memahami dan mengenali dirinya sendiri, $37,5 \%$ mengakui adanya penyesalan yang mereka rasakan, dan $87,5 \%$ merasa lega setelah menulis selama empat hari. Hasil penelitian ini sejalan dengan penelitian Susanti dan Supriyantini (2013) bahwa terapi expressive writing membantu individu untuk memahami dirinya dengan lebih baik, dan menghadapi depresi, distress, kecemasan, adiksi, ketakutan terhadap penyakit, kehilangan, dan perubahan dalam kehidupannya.
Partisipan menulis selama empat hari dengan berbagai tulisan yang berbedabeda tiap harinya. Mereka menuliskan pengalaman-pengalaman yang mengungkapkan permasalahan yang dialami, kemudian memunculkan pemahaman terhadap dirinya sendiri, serta pandangan akan masa depan terkait dirinya. Hal tersebut sesuai dengan pendapat Baikie dan Wilhelm (2005) bahwa expressive writing mengeksplorasi pengalaman traumatis dan emosional yang memungkinkan individu untuk menghadapi trauma, mengakui emosi yang terkait, memahami pemikiran dan dirinya sendiri, serta menurunkan tekanan tubuh.

Hasil uji hipotesis penelitian mengenai pengaruh expressive writing dalam meningkatkan self-esteem pecandu narkoba di program rehabilitasi BNN Baddoka dengan menggunakan uji Wilcoxon menunjukkan nilai signifikansi sebesar $\mathrm{p}=$ $0,026(\mathrm{p}<0,05)$, artinya terdapat pengaruh expressive writing dalam meningkatkan selfesteem pecandu narkoba di program rehabilitasi BNN Baddoka.

Hasil penelitian ini sejalan dengan Skager dan Kerst (1989) bahwa pendekatan alternatif untuk mengukur self-esteem individu adalah dengan memberikan metode untuk menggambarkan diri secara keseluruhan yaitu melalui expressive writing. Pernyataan tersebut diperkuat oleh Lehrhoff (2014) bahwa expressive writing adalah metode yang efektif untuk pengungkapan karena dapat memperbaiki kondisi psikologis.

Hasil penelitian ini menunjukkan bahwa intervensi expressive writing dapat meningkatkan self-esteem pecandu narkoba yang berada dalam program rehabilitasi. Terapi expressive writing dapat digunakan kepada residen yang berada di Balai Rehabilitasi sebagai intervensi yang mencakup kognitif, perilaku, emosi, dan perasaan. Hal ini didukung oleh pendapat Malchiodi (2005) bahwa expressive writing 
dapat digunakan untuk konseling, psikoterapi, rehabilitasi, dan kesehatan, selain itu menurut Rahmawati (2014), juga dapat mengubah sikap, streotipe, kreativitas, memori, motivasi, kepuasan hidup, penampilan, dan berbagai hubungan antara kesehatan dan perilaku.

Kelemahan dalam penelitian ini adalah referensi yang masih sangat kurang mengenai pengaruh expressive writing dalam meningkatkan self-esteem pecandu narkoba, sehingga peneliti lebih banyak menggabungkan teori dari kedua variabel. Kelemahan lain dalam penelitian ini adalah terdapat kesulitan saat memberikan instruksi kepada pecandu narkoba yang memiliki riwayat lama penggunaan narkoba selama bertahun-tahun, hal tersebut memengaruhi kemampuan pecandu narkoba dalam memahami instruksi, sehingga peneliti harus mengulang instruksi beberapa kali.

\section{SIMPULAN DAN SARAN}

Kesimpulan dari penelitian ini ialah bahwa expressive writing efektif dalam meningkatkan self-esteem pecandu narkoba di program rehabilitasi BNN Baddoka. Terdapat perbedaan yang signifikan pada hasil pengukuran pertama dan kedua setelah diberi perlakuan dimana nilai selfesteem subjek (MI, DZ, MAM, MRA, MZH, dan $\mathrm{RF}$ ) pada pengukuran kedua lebih tinggi daripada pengukuran pertama. Berdasarkan hasil penelitian yang diperoleh, saran yang dapat diberikan adalah sebagai berikut:

1. Balai Rehabilitasi BNN dapat menggunakan intervensi expressive writing sebagai salah satu intervensi kepada residen.

2. Bagi pecandu narkoba, expressive writing dapat digunakan untuk meningkatkan self-esteem dengan tujuan menemukan perubahan yang lebih baik dengan adanya pengungkapanpengungkapan mengenai pengalaman atau masalah pribadi melalui media menulis.

3. Peneliti selanjutnya dapat menjadikan penelitian ini sebagai referensi guna melakukan penelitian bertopik sama. Peneliti selanjutnya yang berminat pada topik yang sama, sebaiknya memperhatikan kembali pemberian instruksi kepada subjek pecandu dengan penyampaian yang pelan, mengulang instruksi, dan bertanya kembali kepada mereka hal-hal yang belum dipahami. 


\section{DAFTAR PUSTAKA}

Akhter, A. (2013). Relationship between substance use and self-esteem. International Journal of Scientific, $4(2), 1-7$.

Baikie, K. A., \& Wilhelm, K. (2005). Emotional and physical health benefits of expressive writing. Advances in Psychiatric Treatment,11, 338-346.

Bnn.go.id. (2019). Apa itu psikotropika dan bahayanya. https://bnn.go.id/apaitu-psikotropika-danbahayanya/diakses 19/05/2020.

Cohen, S. M. (2010). Expressive writing as a therapeutic process for drug dependent woman. Disertasi, tidak diterbitkan. Virginia: Commonwealth University.

Coopersmith, S. (1967). The antecedents of self-esteem. USA: W.H. Freeman and Company.

Departemen Pendidikan Nasional. (2011). Kamus besar bahasa indonesia. Jakarta: PT Gramedia Pustaka Utama.

Deputi Bidang Pencegahan. (2017). Narkoba dan permasalahannya. Jakarta: Badan Narkotika Nasional RI.

Gunawan, K, W., Priyatama, A, N., \& Setyanto, A, T. (2016). Pengaruh pelatihan pemaafan terhadap peningkatan self-esteem pecandu narkoba di program re-entry Balai Besar Rehabilitasi Badan Narkotika Nasional Lido, Bogor. Jurnal Psikologi Wacana, 8(16).

Hefferon, K., \& Boniwell, I. (2011). Positive psychology: Theory, research and applications. New York: The McGraw Hill Companies.
Indah, V. P., Afiatin, T., \& Astuti, Y. D. (2011). Menulis pengalaman emosional untuk menurunkan depresi pada perempuan korban kekerasan. Jurnal Intervensi Psikologi, 3(2), 149168.

Kementerian Kesehatan RI. (2014). Data dan informasi kesehatan. Jakarta: Kementerian Kesehatan RI.

Lehrhoff, J. (2014). The benefits of fictional perspective taking in expressive writing. Tesis, tidak diterbitkan. Waltham: Brandeis University.

Malchiodi, C. A. (2005). Expressive therapies: History, theory, and practice. New York: Guilford Publications.

Pennebaker, J. W. (1997). Writing about emotional experiences as a therapeutic process. Psychological Science, 8(3), 162-166.

Rahmawati, M. (2014). Menulis ekspresif sebagai strategi mereduksi stres untuk anak-anak korban kekerasan dalam rumah tangga. Jurnal Ilmiah Psikologi Terapan. 02(02), 276-293.

Santrock, J, W. (2012). Life-span development: Perkembangan masahidup (edisi ketigabelas). Terjemahan oleh Benedictine Wisdyasinta. Jakarta: Penerbit Erlangga.

Skager, R., \& Kerst, E. (1989). Alcohol and drug use and self-esteem: A psychological perspective. In Mecca, Andrew, N. J. Smelser, \& J. Vasconcellos, Handbook of The Social Importance of Self-Esteem (pp.249289). California: University of California press. 
Steffenhagen, R. A. (1980). Self-esteem theory of drug abuse. In Lettieri, D. J., Sayers, M., \& Pearson, H. W, Theories on Drug Abuse (pp.157-163). Washington. D. C: National Institute on Drug Abuse.

Susanti, R., \& Supriyantini, S. (2013). Pengaruh expressive writing therapy terhadap penurunan tingkat kecemasan berbicara di depan umum pada mahasiswa. Jurnal Psikologi, 09(02), 119-129.

Undang-Undang Republik Indonesia Nomor 35 Tahun 2009 tentang Narkotika. Tambahan Lembaran Negara Republik Indonesia Tahun 2009 Nomor 5062.
Volkow, N. D. (2014). The science of addiction: Drugs, brains, and behavior. National Institute on Drug Abuse.

Widyastuti. (2002). Peran status perkawinan poligami dan monogamy orangtua terhadap harga diri, koping, dan depresi. Tesis, tidak diterbitkan. Yogyakarta: Universitas Gadjah Mada.

World Health Organization (WHO). (2016). The health and social effect of nonmedical cannabis use. Switzerland: World Health Organization. 